\section{Peach cultivar BRS Citrino}

\section{Maria do Carmo Bassols Raseira ${ }^{{ }^{*}}$, Rodrigo Cezar Franzon ${ }^{2}$, José Francisco Martins Pereira ${ }^{3}$, Ciro Scaranari ${ }^{2}$ and Nelson Pires Feldberg $^{3}$}

Abstract: 'BRS Citrino' is a highly productive canning peach that has a round to conic shape. The flesh has a sweet acid flavor with a slight bitterness, giving a good quality product when canned. It is adapted to southern Rio Grande do Sul, where the production of processed peaches is concentrated.

Key words: Prunus persica, canning peach, early ripening, low chilling, nonmelting.

\section{INTRODUCTION}

The peach is one of the most important temperate fruit species worldwide. Peach production reached 21.6 million tons, in 2013 (FAO 2015). In the same year, Brazil produced 217.706 tons of peaches on 18.091 ha (FAO 2015). Within Brazil, $65.1 \%$ of these were produced in the state of Rio Grande do Sul; $14 \%$ in São Paulo; $11.8 \%$ in Minas Gerais; $7.5 \%$ in Paraná and 1.6\% in Santa Catarina. Besides the economic importance, peach production has also a great social importance. Thousands of families, mainly in the Southern states of Brazil, depend on peach culture (direct or indirectly) for their main source of income.

There is, generally, a large demand for early or very early ripening peaches, especially in subtropical production areas which supplies fresh fruit to the market before the main temperate production regions. Early peaches give better profit to growers because of their high market price (Byrne et al. 2012) plus their lower costs, since they need less sprays applications.

In Southern Brazil, early peaches ripen in October or the first half of November (Raseira et al. 2015) which allows them to avoid high pressures of pests such as the oriental-fruit-moth. The fruits produced at that time, however, are generally of small size and low solid soluble content (SST), due to the short fruit development period and climatic conditions. Embrapa Clima Temperado released the cv. BRS Bonão, an early peach cultivar for processing, in 2009 (Raseira et al. 2014). This cultivar produces good sized fruits, with an average weight superior to $100 \mathrm{~g}$ and soluble solids content varying from $8^{\circ}$ to $12^{\circ}$ Brix. However, this cultivar is very early blooming which has led to inconsistent production.

The cultivar BRS Citrino, released in 2016, differs from 'BRS Bonão', especially with respect to the production stability. It has performed consistently when winter temperatures had large fluctuations and the temperatures during bloom have reached $28^{\circ} \mathrm{C}$.
Crop Breeding and Applied Biotechnology 18: 234-236, 2018 Brazilian Society of Plant Breeding. Printed in Brazil http://dx.doi.org/10.1590/198470332018v18n2c34 \title{
(n)
}




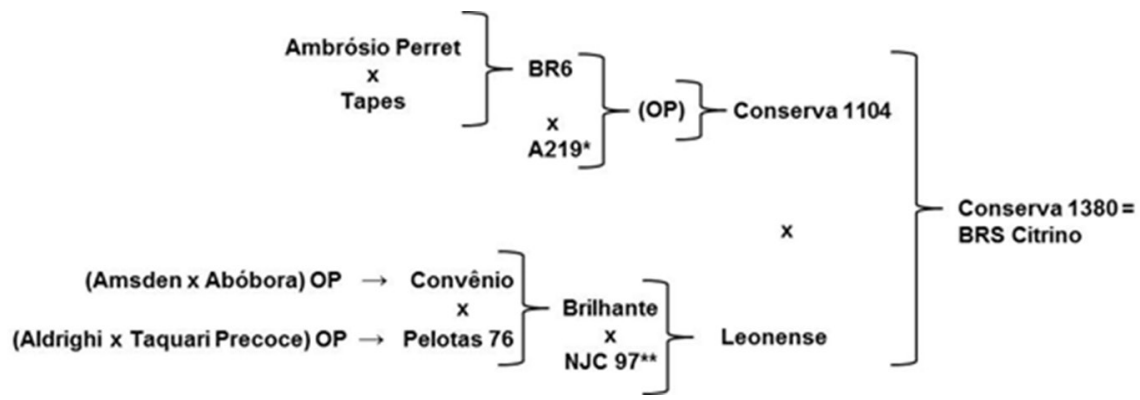

Figure 1. Genealogy of cultivar BRS Citrino. (OP = open pollination; *pollen introduced from the University of Arkansas peach breeding program; **pollen introduced from Rutgers University, New Jersey).

\section{CHARACTERISTICS OF THE CULTIVAR}

\section{Origin}

The cv. BRS Citrino originated from a controlled hybridization made in 2000 , between the selection Conserva 1104 and the cultivar Leonense, both developed by the Embrapa's program (Figure 1). Seeds of this cross were disinfested, stratified and after germination and growth in the greenhouse, the seedling plants were transplanted to the experimental field, in the winter of 2001. Three years later, one plant of this progeny was selected, budded and since then, tested as Conserva 1380. The following year,

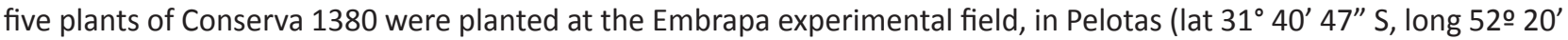
24" W and alt $60 \mathrm{~m}$ as I). In 2013, an observation plot was planted in a local fruit grower's orchard, located in the Pelotas rural area, known as Santa Áurea.

\section{Plants}

The plants of 'BRS Citrino' are medium height and vigor (Figure 2). Flowers are showy with a medium density (on average 15 nodes per $25 \mathrm{~cm}$ branch). Full bloom generally occurs during the last third of July (sometimes by mid July) and harvest generally begins by the first week of November (Tables 1). This is about two weeks before the fruits of cv. Sensação (a cultivar widely planted in Southern Rio Grande do Sul, which produces fruits for canneries) are ripe. 'BRS Citrino' coincides, partially, with the season of cv. Bonão, another canning peach cultivar. It is inferior to this one in size

Table 1. Full bloom data, chilling hours to full bloom and first harvest of the new cultivar, BRS Citrino, and the commercial cvs. BRS Bonão and Sensação

\begin{tabular}{|c|c|c|c|c|c|c|c|c|c|}
\hline \multirow[b]{2}{*}{ Year } & \multicolumn{3}{|c|}{ Full bloom data } & \multicolumn{3}{|c|}{ Chilling hours until full bloom ${ }^{*}$} & \multicolumn{3}{|c|}{ Beginning of harvest } \\
\hline & BRS Citrino & BRS Bonão & Sensação & BRS Citrino & BRS Bonão & Sensação & BRS Citrino & BRS Bonão & Sensação \\
\hline 2006 & $07 / 10$ & $07 / 04$ & $07 / 16$ & 125 & 115 & 125 & - & - & - \\
\hline 2008 & $07 / 12$ & $07 / 07$ & $07 / 23$ & 71 & 71 & 71 & $10 / 21$ & $10 / 21$ & $11 / 04$ \\
\hline 2009 & $07 / 26$ & $07 / 16$ & $08 / 06$ & 291 & 210 & 369 & $11 / 05$ & $11 / 09$ & $11 / 17$ \\
\hline 2010 & $07 / 17$ & $07 / 16$ & $08 / 08$ & 162 & 150 & 331 & $11 / 05$ & $11 / 10$ & $11 / 17$ \\
\hline 2012 & $07 / 19$ & $07 / 03$ & $08 / 01$ & 342 & 169 & 436 & $10 / 30$ & $10 / 30$ & - \\
\hline 2013 & $07 / 11$ & $* *$ & $* *$ & 95 & - & - & $10 / 30$ & No crop & No crop \\
\hline 2014 & $07 / 16$ & $07 / 10$ & 08/02 & 64 & 64 & 109 & $10 / 21$ & No crop & $10 / 29$ \\
\hline 2015 & $07 / 24$ & $06 / 28$ & 08/07 & 74 & 57 & 74 & $11 / 08$ & $10 / 30$ & $11 / 05$ \\
\hline
\end{tabular}

- Missing data; ${ }^{*}$ Chilling hours $\leq 7.2^{\circ} \mathrm{C} ; * *$ extended bloom and no clear dates for full bloom.

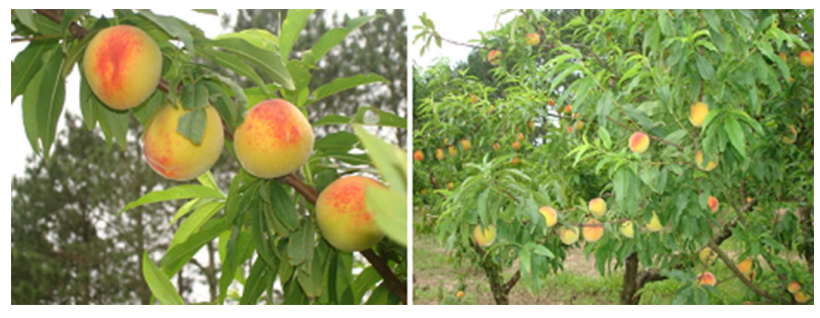

Figure 2. Fruits of 'BRS Citrino', on adult plants, at Experimental Field of Embrapa Clima Temperado, in 2015. (Photo: José F.M. Pereira). 
Table 2. Production and average fruit weight of the new cultivar, BRS Citrino and the commercial cvs. BRS Bonão and Sensação, in the collection orchard of Embrapa Clima Temperado

\begin{tabular}{|c|c|c|c|c|c|c|}
\hline \multirow[b]{2}{*}{ Year } & \multicolumn{3}{|c|}{ Production $^{*}$} & \multicolumn{3}{|c|}{ Average fruit weight (g) } \\
\hline & BRS Citrino & BRS Bonão & Sensação & BRS Citrino & BRS Bonão & Sensação \\
\hline 2006 & 4 & - & - & - & 122 & - \\
\hline 2007 & 4 & $3-4$ & 3 & 89 & 140 & 124 \\
\hline 2008 & 5 & 3 & 3 & - & 121 & 100 \\
\hline 2009 & $3-4$ & 3 & 3 & 129 & 170 & 135 \\
\hline 2010 & 4 & 3 & 2 & 118 & 87 & 95 \\
\hline 2013 & 5 & 2 & 1 & 126 & - & - \\
\hline 2014 & 2 & 1 & 2 & 130 & - & 78 \\
\hline 2015 & 4 & $0-1$ & $3-4$ & 116 & 90 & 103 \\
\hline
\end{tabular}

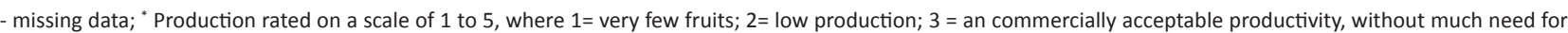
thinning; $4=$ high productivity needing a lot for thinning; and 5 = excessive yield

and soluble solids content but superior in productivity, yield stability, fruit shape and color, as well as, in texture after processed.

\section{Fruits}

'BRS Citrino' produces round to conic shaped fruits (Figure 2), without pronounced tip. Fruit size varies with the year, with a diameter between $5.4 \mathrm{~cm}$ and $7.4 \mathrm{~cm}$, according to management and the weather conditions.

The productivity was acceptable or high, in nine (9) out of 10 years and more consistent than both 'BRS Bonão' and 'Sensação' (Table 2).

The skin is yellow with $30 \%$ of the surface covered by red, sometimes reaching up to 60 to $70 \%$ (Figures 2 and 3). Flesh is non-melting and medium firm. The fruits have a sweet acid flavor with predominance of the acidity, giving a good taste when canned in syrup. The soluble solids content is usually low (Table 3 ) which makes this cultivar not suitable for the juice or the fresh market, in spite of the attractive appearance.

\section{Availability}

Plants of this cultivar can be obtained in the nurseries licensed by Embrapa, which are listed on the following site: https://www.embrapa.br/produtos-e-mercado/pessego.

\section{REFERENCES}

Byrne DH, Raseira MCB, Bassi B, Piagnani MC, Gasic K, Reighard GL, Moreno MA and Perez S (2012) Peach. In Badenes ML and Byrne D (eds) Fruit breeding. Springer Science Business Media, LLC, Philadelphia, p. 505-565.

FAO (2015) FAOSTAT - Food and Agriculture Organization of the United Nations; Statistical Division. Roma. Avaliable at <http://faostat3.fao.
Table 3. Average total soluble solids content ( ${ }^{\circ} \mathrm{Brix}$ ) of the new cultivar, BRS Citrino and the commercial cvs. BRS Bonão and Sensação

\begin{tabular}{lccc}
\hline Year & BRS Citrino & BRS Bonão & Sensação \\
\hline 2006 & - & 10.9 & - \\
2007 & 6.0 & 11.1 & 11.1 \\
2008 & 8.0 & 10.0 & 8.9 \\
2009 & 9.1 & 8.8 & 10.2 \\
2010 & 11.2 & 15.4 & - \\
2011 & 11.6 & - & 10.1 \\
2012 & 8.7 & 7.4 & 11.2 \\
2013 & 7.4 & - & - \\
2014 & 7.9 & - & 10.8 \\
2015 & 8.2 & 8.5 & 9.0 \\
\hline
\end{tabular}

- missing data 